(From the Zoölogical Laboratory of the University of Micbigan, Ann Arbor, Mich., U. S.A.)

\title{
THE EFFECT OF INTENSITY AND DURATION OF LIGHT AND OF DURATION OF DARKNESS, PARTLY MODIFIED BY TEMPERATURE, UPON WING-PRODUCTION IN APHDS ${ }^{1}$.

\author{
By
}

A. Franklin Shull.

With 9 figures in the text.

(Eingegangen am 30. Januar 1929.)

It has been shown (SHuLr 1928) that wingless females of the aphid Macrosiphum solanifolii, when reared in either continuous light or continuous darkness produce mostly wingless offspring; but that when they are alternated between light and darkness of various specified periods their offspring are nearly all winged. Winged parents, when not producing gamic offspring, respond, in general, in the same way to light, though the proportion of winged offspring is usually smaller than in the families of wingless parents similarly treated. The effect of light is directly on the aphids, not indirectly through the plants. It occurs at a fairly definite period of development, which is at some time within the last two days before birth; the young aphids can not be altered by treatment after birth.

An understanding of the physiological processes involved in the abovedescribed action of light awaited further discoveries relating to the effects of different intensities and different durations of the light, to the influence of temperature, and perhaps to wave-length of the light. The experiments described in this paper are part of an attempt to reach a physiological explanation of the control of wing-development ${ }^{1}$.

\section{Methods of Controlling Light.}

In the early part of the new work with duration of light and darkness, in which two successive periods (light and darkness, respectively) totaled in each case 24 hours, lights were turned on and off by hand. Differing intensities were obtained partly by distance from the source of light, partly by use of different electric bulbs in a long enclosure surrounded by black cloth in a darkened room, and all were measured with a Macbeth illuminometer.

1 My thanks are due to Professors T.H. Morgan and Selag Hecht for generously placing at my disposal equipment and space in the laboratories of Columbia University for part of the work, during a sojourn of several months in New York City, and for their active interest in the prosecution of the experiments.

W. Roux' Archiv f. Entwicklungsmechanik Bd. 115. 
In the later experiments, after it had been ascertained that high intensities were not necessary, and that the problem of temperature control during the lighted period could be solved by the use of lamps of low candle-power, the aphids were set in wood-and-metal chambers, completely closed and blackened inside, with the insects 1 meter from the lamp. These blackened chambers were opened only once in two or three days when the aphids were transferred to fresh plants, an operation requiring about 4 minutes, on the average: So far as practicable this transfer was made when the insects were in the light anyway but experiments described in this paper lead to the belief that exposure to moderate light for such short and infrequent periods could not seriously affect wing-production.

In these closed chambers the lamps were turned on and off by electromagnetic relays operated by circuits passing through a drum revolving at uniform speed. The drum was covered with stenciled paper, and pointers passed over this stencil as the drum revolved. When contact was made between pointer and drum, through the windows of the stencil, the lights were turned on. For short periods, a slow speed kymograph with pendulum control, revolving once in about 18 hours, was used. The greatest error observed in the length of such periods was less than 1 minute. For long periods the drum of a thermograph run by clockwork and revolving once a week was employed. The greatest error observed in the length of periods so determined was about 14 minutes.

Maximum-minimum thermometers kept in some of these closed chambers showed that the temperature was not appreciably increased when the lights were turned on. The temperature at the end occupied by the aphids followed closely that of the air just outside its thin wall. Ventilation of the entire set of chambers from the compressed-airsystem was sometimes practised, but made no observable difference in the temperature.

\section{Effect of Various Intensities and Periods of Light.}

The effects of exposure to light of six different intensities ranging from 5 to 10000 meter-candles, for daily periods ranging from 5 minutes to 24 hours, were tested in a series of experiments. These were necessarily performed at several different times, but were on the whole so concordant that they are all described together. The daily exposures to light were rather fully studied at one of the intensities (5 meter-candles). At the other intensities, enough periods of exposure were employed, particularly at the critical points, to establish the nature of the curve of wing-production. Table 1 gives the percentages of winged females, based on 75 to 300 individuals, in all of the experiments. These percentages are plotted graphically in Fig. 1. The offspring produced in the first two or three days after the beginning of the experimental treatment have been omitted, so that the results of previous treatment of the parents are excluded.

The eurves in Fig. 1 have the following three noteworthy features. First, all of them rise rapidly with increase of the daily time of exposure to light, up to a certain maximum. In the curve for 5 meter-candles, this maximum is at 8 hours of exposure. All of the other curves are truncated at the top by the impossibility of producing more than 100 per cent of winged offspring. Where their maxima would be, were it possible to rise 
Light, Darkness, Temperature and the Wings of Aphids.

above the level of 100 per cent., can only be judged by analogy with the curve for 5 meter-candles. Second, the greater the intensity of the light

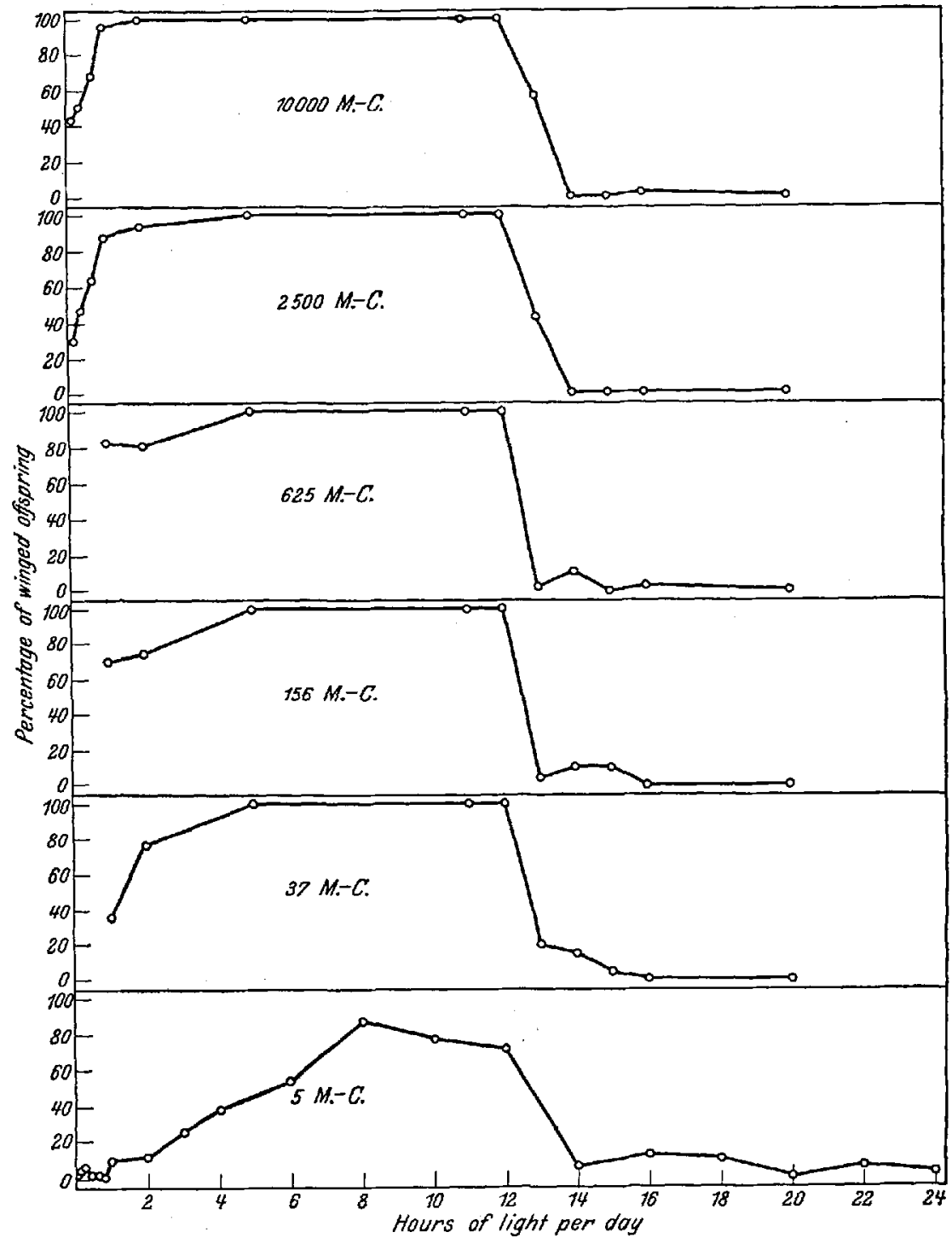

Fig. 1. Showing the effect of alternating darkness with light of six different intensities, once every 24 hours, upon wing-production in the offspring of the aphids so treated. The data are those of Table 1. Note the rapid rise of the leit ends of the curves, the greater height of the left ends of the curves for the higher intengities, and the sharp drop at the middle of each curve where the periods of darkness fall below 12 hours.

used, the higher (in general) is the curve of wing-production at the left end, representing the shorter exposures. This relation is better shown in 
A. F. Shull:

Table 1. Showing the percentage of winged offspring of wingless females exposed daily to light of various intensities for various periods.

\begin{tabular}{|c|c|c|c|c|c|c|c|}
\hline \multirow{2}{*}{ Time } & \multirow{2}{*}{$\begin{array}{l}\text { of Exposure } \\
\text { (Dally) }\end{array}$} & \multicolumn{6}{|c|}{$\begin{array}{l}\text { Percentage of Winged Offspring at the Following Intensities } \\
\text { (in Meter-Candles) }\end{array}$} \\
\hline & & 5 & 37 & 156 & 625 & 2500 & 10000 \\
\hline 5 & Minutes & 2.5 & & & & & \\
\hline 10 & " & 3.1 & & & & 29.7 & 43.4 \\
\hline 20 & $"$ & 5.8 & & & & 47.7 & 50.9 \\
\hline 30 & , & 1.1 & & & & & \\
\hline 40 & " & 2.6 & & & & 63.6 & 68.7 \\
\hline 50 & ", & 0.0 & & & & & \\
\hline 1 & Hours & 9.0 & 36.4 & 70.0 & 83.0 & 88.7 & 95.7 \\
\hline 2 & , & 11.1 & 77.1 & 74.6 & 81.8 & 94.1 & 100.0 \\
\hline 3 & $"$ & 25.0 & & & & & \\
\hline 4 & $"$ & 37.8 & & & & & \\
\hline 5 & , & & 100.0 & 100.0 & 100.0 & 100.0 & 100.0 \\
\hline 6 & $"$ & 53.2 & & & & & \\
\hline 8 & , & 87.9 & & & & & \\
\hline 10 & , & 77.2 & & & & & \\
\hline 11 & , & & 100.0 & 100.0 & 100.0 & 100.0 & 100.0 \\
\hline 12 & , & 71.6 & 100.0 & 100.0 & 100.0 & 100.0 & 100.0 \\
\hline 13 & , & & 20.8 & 4.5 & 1.7 & 42.9 & 56.3 \\
\hline 14 & " & 5.7 & 15.2 & 10.5 & 10.8 & 0.0 & 0.0 \\
\hline 15 & , & & 4.4 & 10.0 & 0.0 & 0.0 & 0.0 \\
\hline 16 & , & 12.6 & 0.0 & 0.0 & 1.9 & 0.0 & 2.3 \\
\hline 18 & , & 9.8 & & & & & \\
\hline 20 & $"$ & 0.0 & 0.0 & 0.0 & 0.0 & 0.0 & 0.0 \\
\hline 22 & , & 5.5 & & & & & \\
\hline 24 & , & 2.2 & & & & & \\
\hline
\end{tabular}

Fig. 2 in which the horizontal axis is much more elongated than in Fig. 1. If the percentage of wing-production be plotted against intensity (the exposure being constant), the curves are of the form shown in Fig. 3 . The number of determined points in these curves is small, even in those for 1-hour and 2-hour exposures, but in general they are of such form as to suggest a mathematical relation between intensity and time and the effect on wing-production. Third, all of the curves show a sharp drop between 12 hours and 14 hours of daily exposure to light, from 100 per cent winged offspring (at all but the lowest intensity) to near zero. All of them remain very low for daily exposures between 14 and 24 hours.

As is shown by other experiments described below, this sharp decrease of wing-production is not due to any important difference between 12 hours and 14 hours of light, but to a striking difference between the effects of the accompanying 12 hours and 10 hours of darkness. 


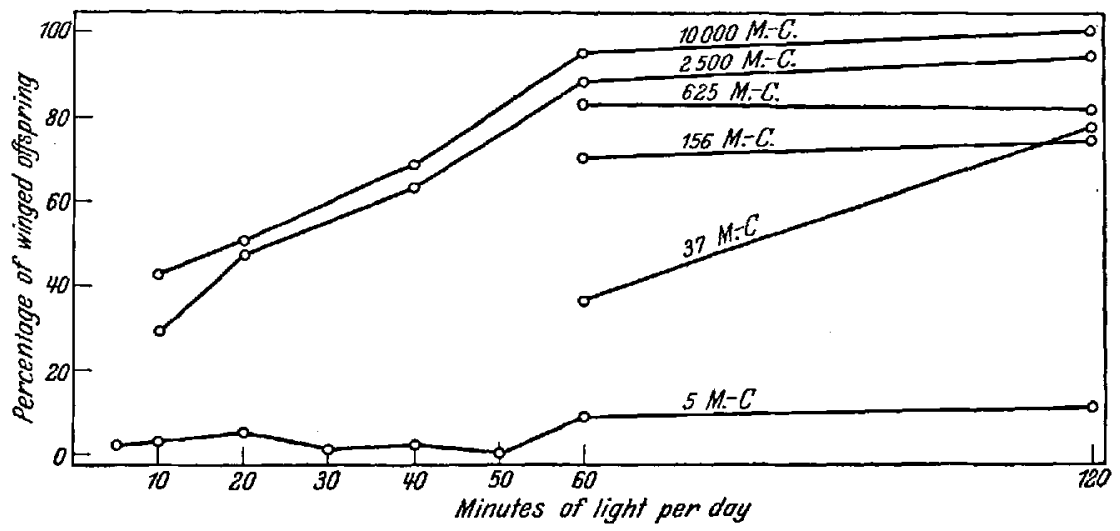

Fig. 2. Showing the effect of intensity and duration of the shorter periods of light upon wingproduction in the offspring. These curves are the left ends of the curves in Fig. 1, greatly elongated horizontaly. Note that the curves for the higher intensities are higher than those for the lower intensities, and that in general, for the short durations, the greater the duration the more wings are produced.

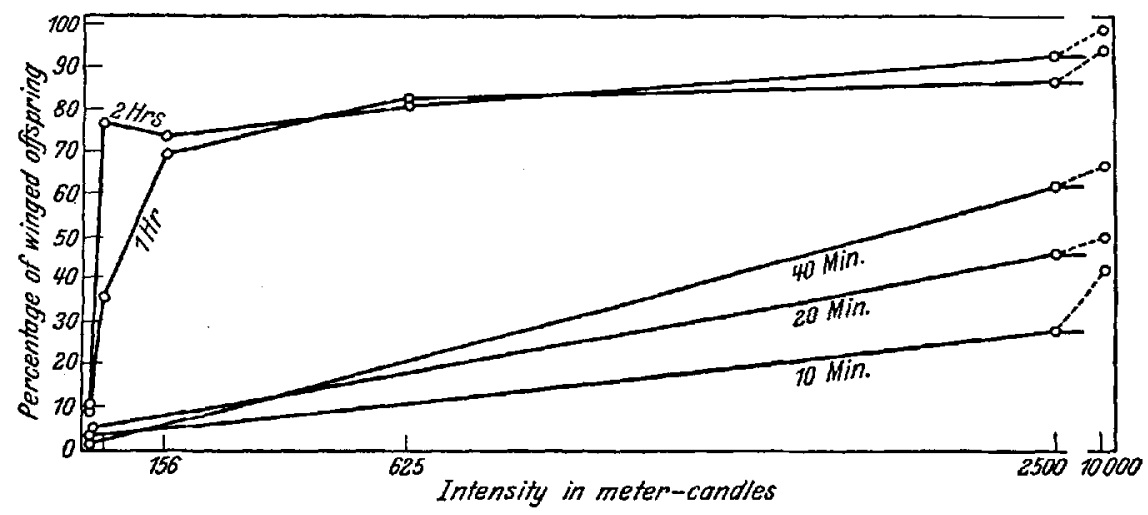

Flg. 3. Showing the relation of intensity of light to wing-production in the offspring of aphids. The data are taken from Table 1, and are arranged so that, for each duration, the intensity is plotted against the percentage of wing-production. The curves for 1 hour and 2 hours are sufflciently complete and regular to suggest that the relation between intengity and wing-production could be approximately expressed by a mathematical formula.

\section{Effect of Alternating Different Intensities of Light.}

Whether alternating two different intensities of light would produce the same effect as alternating light with darkness was shown by the following experiment. Seven to ten wingless aphids were put on each of nine plants. All were kept in light of about 9000 meter-candles intensity for 8 hours daily, and at different lower intensities ranging from 950 meter-candles to total darkness for the other 16 hours. Table 2 shows the results. Some irregularity in the percentage of winged offspring occurs when the lower intensity is below 60 meter-candles, but there is 
an unmistakably greater effect when the lower intensity is 1,6 metercandles. The irregularity at moderately low intensities is perhaps due partly to the fact that, as the experiments were conducted, it was impossible to illuminate all the aphids equally. An aphid on the shady side, or in a cluster of thick leaves, of a plant exposed to only 16 metercandles, for example, may be in light of less than 1,6 meter-candles.

Table 2. Showing the nature of the offspring of wingless aphids reared 8 hours daily in light of 9000 meter-candles intensity, and 16 hours daily in the various lower intensities indicated in the table.

\begin{tabular}{c|c|c|c|c}
\hline \multicolumn{2}{l|}{ Intensity of Light in Meter-Candles } & \multicolumn{3}{|c}{ Offspring } \\
\hline 8 hours daily & 16 hours daily & Wingless & Winged & $\begin{array}{c}\text { Percentage } \\
\text { winged }\end{array}$ \\
\hline 9000 & 950 & 221 & 0 & 0.0 \\
9000 & 323 & 116 & 0 & 0.0 \\
9000 & 97 & 85 & 1 & 1.2 \\
9000 & 59 & 197 & 11 & 5.3 \\
9000 & 26 & 65 & 1 & 1.5 \\
9000 & 16 & 76 & 13 & 14.6 \\
9000 & 4.3 & 251 & 27 & 9.7 \\
9000 & 1.6 & 228 & 205 & 47.3 \\
9000 & 0.0 & 45 & 772 & 94.5
\end{tabular}

Alternation between a single low intensity (1,6 meter-candles) for 16 hours daily and various higher intensities for 8 hours daily was likewise tested, with the results shown in Table 3 . The increase of wing-production, with increase of the higher intensity, began perhaps when this intensity reached 97 meter-candles. Certainly the increase was signi-

Table 3. Showing the nature of the offspring of wingless aphids reared in light of various high or intermediate intensities for 8 hours daily, and in 1,6 meter-candles for 16 hours daily.

\begin{tabular}{c|c|c|r|c}
\hline \multicolumn{2}{c|}{ Intensity of Light in Meter-Candles } & \multicolumn{3}{|c}{ Offspring } \\
\cline { 3 - 5 } 8 hours daily & 16 hours daily & Wingless & Winged & $\begin{array}{c}\text { Percentage } \\
\text { winged }\end{array}$ \\
\hline 1.6 & 1.6 & 119 & 0 & 0.0 \\
4.3 & 1.6 & 168 & 5 & 2.9 \\
16 & 1.6 & 118 & 0 & 0.0 \\
59 & 1.6 & 108 & 1 & 0.9 \\
97 & 1.6 & 126 & 7 & 5.3 \\
323 & 1.6 & 124 & 21 & 14.5 \\
950 & 1.6 & 112 & 42 & 27.3 \\
9000 & 1.6 & 228 & 205 & 47.3
\end{tabular}


ficant when the higher intensity was 323 meter-candles. It seems unlikely that any feasible intensity would be much more effective than the 9000 meter-candles used.

\section{Light and Darkness in Ratio of $1: 2$.}

Since in the preceding experiments and in those already published (SHUL, 1928) the maximum wing-production was obtained with 8 hours of light alternated with 16 hours of darkness, it seemed possible that the mere ratio of these times was what determined the extent of the effect of the alternation. To test this possibility, groups of aphids were subjected to various alternating periods of light and darkness, always in the ratio of $1: 2$. The shortest periods were 15 minutes and 30 minutes, respectively; the longest ones 16 hours and 32 hours, respectively. Almost all of the these experiments were performed in the black-lined boxes, described above, with light of about 22 meter-candles intensity, controlled by stencils on revolving drums as described. It was impossible to cover the entire range of periods at one time, in the apparatus available hence the experiment was performed in sections, each part being repeated several times. Some irregularity was introduced in this way, because the percentage of wing-production varies somewhat from time to time for reasons as yet unknown. That is, there is at least one factor besides light and temperature that has not been controlled. This factor is obviously less potent than light, but causes the percentages to vary. In this particular set of experiments, most of the wings produced in the periods shorter than 5 hours and 10 hours, respectively, were obtained at approximately the same time when wings were specially abundant. No other test of these same short periods yielded so many wings, and no other part of the range of periods was tested at the same time. Hence the curve of wing-production for these short periods is probably relatively higher than it would have been if all periods in the chosen range could have been simultaneously tested. Nevertheless, the facts are given as obtained, without any attempt at adjustment. They appear in Table 4, and are graphically represented in Fig. 4.

The curve is low for all periods shorter than 5 hours and 10 hours, respectively. From periods of 5 and 10 hours up to periods of $6^{1 / 4}$ and $12 \frac{1}{2}$ hours, there is a very rapid increase in wing-production. A maximum reached at the latter point is nearly maintained up to 8 and 16 hours, beyond which a continuous decline sets in. This decline is probably extended over a wide range, and no attempt has been made to trace it. Its limit is presumably the practical absence of winged offspring, as when the parents are raised in continuous light.

If adjustment were made to cancel the effect of the unusually high proportion of winged offspring obtained in one test of each of the short 
Table 4. Showing the percentage of winged offspring produced by wingless aphids that were alternated between light and darkness of various durations in the ratio of $1: 2$.

\begin{tabular}{|c|c|c|c|c|}
\hline \multicolumn{2}{|c|}{ Lengths of Periods, in Hours } & \multicolumn{3}{|c|}{ Offspring } \\
\hline Light & Darkness & Wingless & Winged & $\begin{array}{l}\text { Percentage } \\
\text { winged }\end{array}$ \\
\hline 0.25 & 0.5 & 144 & 2 & 1.4 \\
\hline 1 & 2 & 200 & 33 & 14.2 \\
\hline 2 & 4 & 315 & 27 & 8.7 \\
\hline 3 & 6 & 198 & 36 & 15.4 \\
\hline 4 & 8 & 383 & 44 & 10.3 \\
\hline 5 & 10 & 221 & 42 & 16.0 \\
\hline 5.25 & 10.5 & 116 & 30 & 20.5 \\
\hline 5.5 & 11 & 149 & 55 & 27.0 \\
\hline 5.75 & 11.5 & 110 & 81 & 42.4 \\
\hline 6 & 12 & 148 & 215 & 59.2 \\
\hline 6.25 & 12.5 & 48 & 156 & 76.5 \\
\hline 7 & 14 & 65 & 193 & 74.4 \\
\hline 8 & 16 & 54 & 150 & 73.5 \\
\hline 9 & 18 & 74 & 172 & 69.9 \\
\hline 10 & 20 & 97 & 112 & 53.6 \\
\hline 12 & 24 & 161 & 99 & 38.1 \\
\hline 16 & 32 & 131 & 60 & 31.4 \\
\hline Continuous & 0 & 544 & 13 & 2.3 \\
\hline
\end{tabular}

periods, the left half of the curve in Fig. 4 would be lowered, or the right half would be raised. In either case the marked rise between the $5: 10$

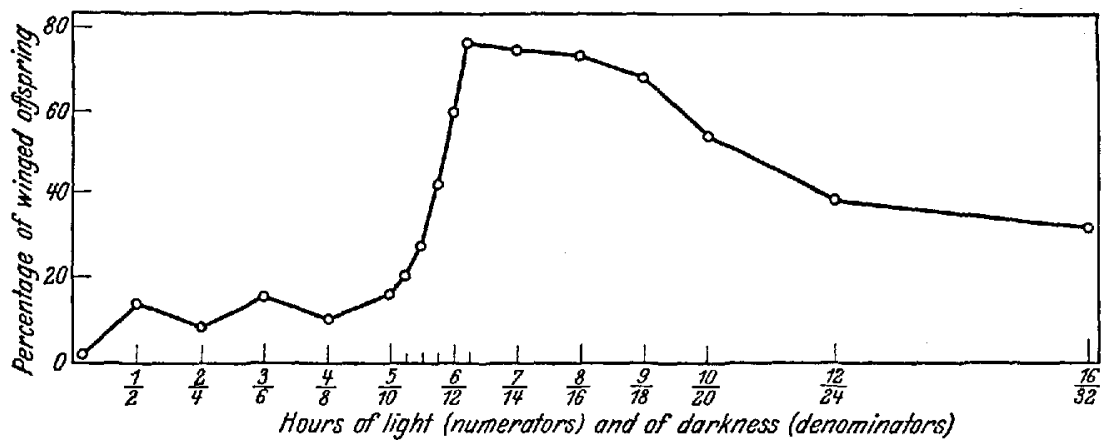

Fig. 4. Showing the effect, upon wing-production in aphids, of alternating tbeir parents between light and darkness in the time ratio of $1: 2$ but of various absolute lenghts. The sharp rise near the middle of the curve is due to the fact that the period of darkness there approaches 12 hours in length. The short periods (at left end of curve) have only a small effect, and there is reason for believing that they are really even less effective than the curve indicates.

and the $6,25: 12,5$-hour periods would be accentuated. Obviously between either 5 and 6,25 hours of light, or 10 and 12,5 hours of dark- 
ness, or both, there is a very significant difference with respect to wing-production. It may be recalled that a similar sharp change was observed in Fig. 1, where each curve suffered a sharp drop at its middle point. Beyond this point in each curve the period of light increased above 12 hours, and the period of darkness fell below 12 hours. This fact, taken in conjunction with the sharp rise shown in the curve of Fig. 4, suggests that, at least in this range of periods, it is the length of the period of darkness rather than that of the light that is of prime importance in determining how many winged offspring shall be produced. Experiments described later tend to confirm this suggestion.

\section{Light and Darkness in Ratios Other Than 1:2.}

The preceding section offered no satisfactory evidence that the mere ratio of duration of light to that of darkness determines whether winged

Table 5. Showing the effect of light and darkness in the time ratios of $1: 1,1: 2$, $1: 3$, and $1: 4$, for several different durations, upon wing-production in the offspring of aphids.

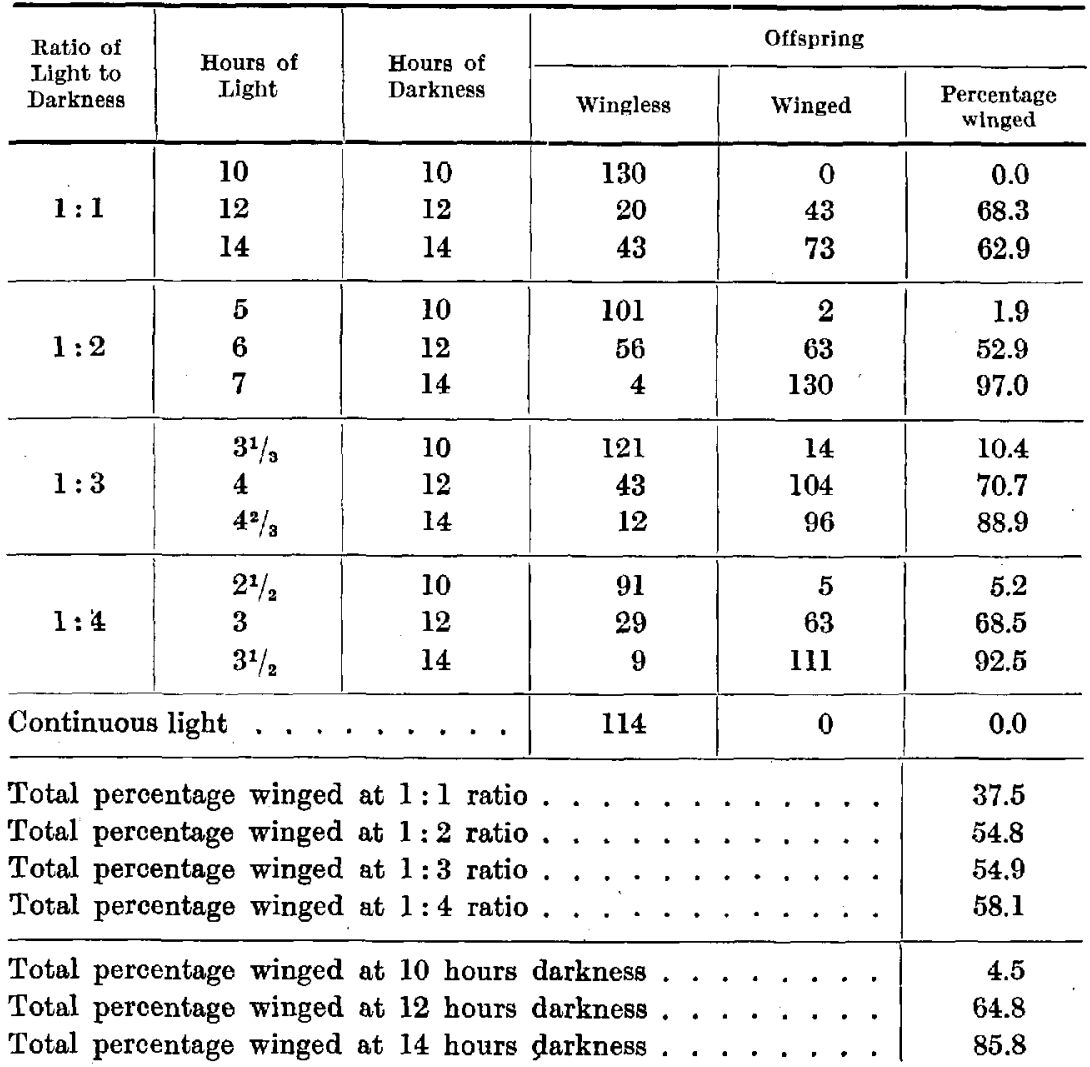


offspring shall be produced. Since only the ratio $1: 2$ was tested, it seemed advisable to experiment with other ratios. The ratios used were $1: 1,1: 2,1: 3$ and $1: 4$, the ratio $1: 2$ being repeated in order to make a comparison with the previous work. Use was made of the probable fact that a period of darkness at least 12 hours long is necessary in order to get many winged offspring. The periods chosen were therefore 10 , 12 , and 14 hours of darkness, while the periods of light were made equal to and $1 / 2,1 / 3$ and $1 / 4$ of these, respectively. All of these tests were performed simultaneously to obtain the greatest degree of comparability of the results. The numbers obtained in the several groups are shown in Table 5, at the bottom of which some of the significant data are summarized.

The summarized data show that equal duration of light and darkness is not as effective in producing wings as are shorter periods of light. There is no great difference, however, between light periods one-half as long as the alternating dark periods and light periods one-third or onefourth as long. What evidence there is goes to show that the shorter light periods were the more effective. This does not mean, necessarily, that more was accomplished by short duration of light. The greater effectiveness of the short periods may be due to the fact that the alternation could be repeaied more frequently.

Table 5 also bears upon the question, discussed in the preceding section, of the effectiveness of periods of darkness in the neighborhood of 12 hours in length. The last three lines of the table collect the pertinent information. Ten hours of darkness, no matter what the duration of light, hardly sufficed for the production of wings. This tends to confirm the suspicion that the left half of the curve in Fig. 4 is somewhat too high. Also, fourteen hours of darkness were more effective than twelve, just as they were in Table 4. Possibly, as in Table 4, a still greater effect would have been obtained by some dark period between 12 and 14 hours.

\section{Alternation of 12 Hours of Darkness With Various Periods of Light.}

One conclusion which must apparently be drawn from the preceding experiments is that the periods of darkness used must be not less than about 12 hours long to obtain the maximum amount of wing-production. Table 5 contains a suggestion that, if such periods of darkness are employed, it makes little difference what is the duration of the light, within certain limits. How the duration of the light affects the amount of wing-production was determined by alternating a number of groups of wingless aphids between 12 hours of darkness and various periods of light, as indicated in Table 6 where the results of the experiment are given. Fig. 5 represents the same data graphically. 
Periods of light ranging from 2 to 6 hours, when alternated with 12-hour periods of darkness, were about equally effective. With longer periods of light there is a rapid dimunition of the effectiveness, until at 20 hours of light the alternation has practically no consequence.

Table 6. Showing the effect, upon wing-production in aphids, of alternating their wingless parents between 12 hours of darkness and the various periods of light indicated in the first column below.

\begin{tabular}{c|r|r|r}
\hline \multirow{2}{*}{$\begin{array}{c}\text { Hours of } \\
\text { Light }\end{array}$} & \multicolumn{3}{|c}{ Offspring } \\
\cline { 2 - 4 } & Wingless & Winged & $\begin{array}{c}\text { Percentage } \\
\text { winged }\end{array}$ \\
\hline 1 & 116 & 54 & 31.8 \\
2 & 39 & 113 & 74.3 \\
3 & 48 & 139 & 74.3 \\
4 & 33 & 92 & 73.6 \\
6 & 46 & 134 & 74.4 \\
8 & 199 & 285 & 58.9 \\
10 & 132 & 159 & 54.6 \\
12 & 278 & 129 & 31.7 \\
16 & 394 & 61 & 13.4 \\
20 & 315 & 8 & 2.5 \\
24 & 321 & 7 & 2.1 \\
28 & 329 & 9 & 2.4 \\
\hline Continuous & 318 & 3 & 0.9 \\
light & & &
\end{tabular}

Although the curve is practically flat-topped from 2 to 6 hours of light, it is probable that the 6-hour periods must be regarded as individually

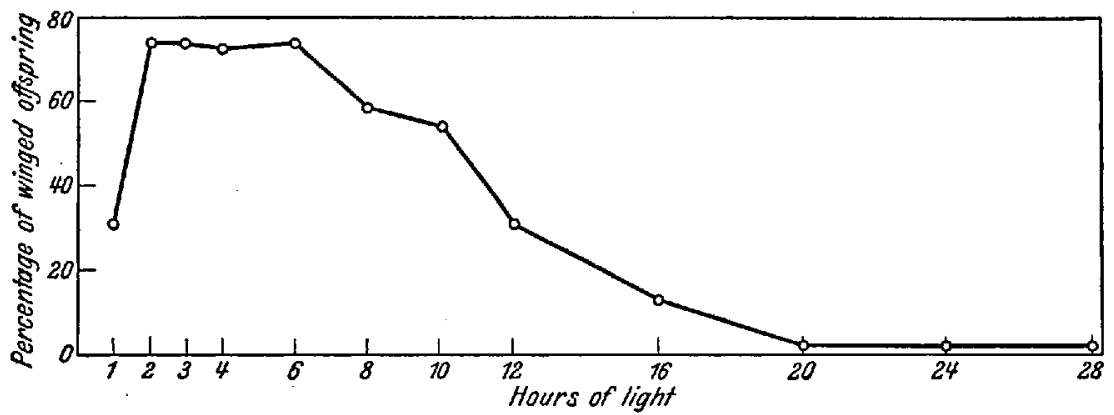

Fig. 5. Curve showing the effect, upon wing-production, of alternating aphids between 12 hours of darkness and various periods of light. Though the curve seems to indicate equal effects by all light periods from 2 to 6 hours, it is probable that the b-hour periods were individually the most effective, since they were repeated least frequently.

more effective than the 2-, 3-, or 4-hour periods. The 2-hour periods were repeated every 14 hours, the 3 -hour periods every 15 hours, the 
4-hour periods every 16 hours, and the 6-hour periods every 18 hours. Since their total effects were about equal, each 6-hour period may be calculated to have produced an effect roughly 1,3 times as great as that produced by each single 2 -hour period, about 1,2 times as much as each single 3-hour period, and so on. The maximum effect would appear to be produced, therefore, by 6 hours of light. All this is in relation, of course, to alternation with 12-hour periods of darkness, and may have no value in any other relation.

\section{Alternation of 6 Hours of Light With Various Periods of Darkness.}

When it had been concluded, as above, that 6 hours of light is the most effective period, in alternation with 12-hour periods of darkness, it was obviously desirable to alternate this period of light with various periods of darkness. This was done, with the results shown in Table 7 and Fig. 6.

The curve of wing-production is low (Fig. 6) for all periods of darkness up to 10 hours, whence it rises rapidly to a maximum at 12 to 14 hours of darkness, then falls gradually as the duration of darkness increases.

Table 7. Showing the effect, upon wing-production in aphids, of alternating their wingless parents between 6 hours of light and the various periods of darkness indicated in the first column below.

\begin{tabular}{c|c|c|c}
\hline \multirow{2}{*}{$\begin{array}{c}\text { Hours of } \\
\text { Darkness }\end{array}$} & \multicolumn{3}{|c|}{ Offspring } \\
\cline { 2 - 4 } & Wingless & Winged & $\begin{array}{c}\text { Percentage } \\
\text { winged }\end{array}$ \\
\hline 2 & 157 & 0 & 0.0 \\
4 & 133 & 0 & 0.0 \\
6 & 155 & 7 & 4.3 \\
8 & 184 & 3 & 1.6 \\
10 & 141 & 13 & 8.4 \\
11 & 84 & 81 & 49.1 \\
12 & 27 & 135 & 83.3 \\
13 & 23 & 141 & 86.0 \\
14 & 28 & 137 & 83.0 \\
16 & 62 & 140 & 69.3 \\
18 & 75 & 141 & 65.3 \\
20 & 130 & 149 & 53.4 \\
\hline Continuous & 175 & 9 & 4.9 \\
light & & & \\
\hline
\end{tabular}

The rapid rise of this curve as the period of darkness approaches 12 hours recalls the similar rise at approximately 12 hours of darkness in Fig. 4, and the striking difference between the effects of 10 hours and 12 hours of darkness shown in Table 5. The reason is doubtless the same in all 
cases. Some change that occurs in darkness either takes place with great rapidity after about 10 hours have elapsed, or reaches a critical point about that time.

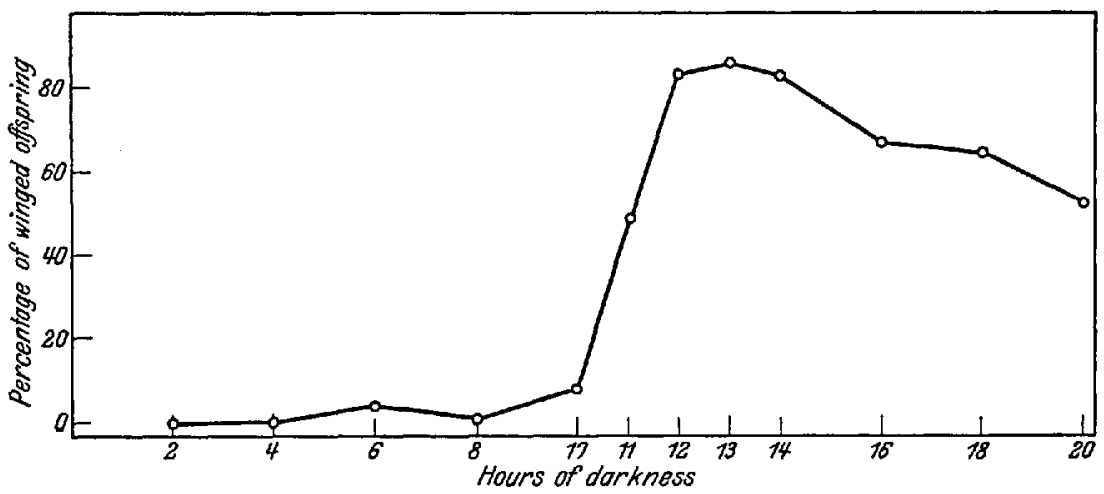

Fig. 6. Curve showing the effect, upon wing-production, of alternating the aphids between 6 hours of light and various periods of darkness. The sharp rise between 10 and 12 hours of darkness has the same explanation as the similar rise in Fig. 4, the less marked rises at the corresponding points in Figs. 7 and 8, and the sudden drops in all curves of Fig. 1.

\section{One Exposure to Light or Darkness Insufficient.}

In the hope of demonstrating a simple relation between time and intensity of illumination and the percentage of winged offspring, comparable to the Roscoe-Bunsen law, I tested the effects of single exposures to light and darkness.

Single exposures to darkness were easily effected. Stocks of aphids in continuous light were gradually, over a period of 12 hours, brought to light of five different intensities ranging from 37 to 10000 meter-candles. They were then left a further 12 hours or more at the new intensities. Five lots of aphids were taken from each of the five intensities of light. One lot from each intensity was left continuously in light of that inten. sity, while the other four were placed in total darkness for different periods. Thereafter each lot was brougat back to light of the same intensity as that to which it was previously exposed. All offspring produced by these aphids within 4 days after the period of darkness were recorded, as in Table 8.

In this table it is probably significant that none of the aphids not exposed to darkness produced any winged offspring (first line of each group of five in table 8), showing that the gradual change to the several intensities of light did not stimulate wing-production. It is perhaps also significant that none of the parents removed from 37 meter-candles to darkness produced any winged offspring. Probably it must be concluded, therefore, that a single exposure to darkness from light of the higher intensities stimulated the production of some wings. The effect was 
Table 8. Showing the effect of a single exposure to darkness, for various periods and from various intensities of light, on the offspring of the treated aphids.

\begin{tabular}{|c|c|c|c|}
\hline \multirow{2}{*}{$\begin{array}{l}\text { Intensity of Light } \\
\text { in Meter-Candles }\end{array}$} & \multirow{2}{*}{$\begin{array}{l}\text { Duration of Darkness } \\
\text { in Hours }\end{array}$} & \multicolumn{2}{|c|}{ Offspring } \\
\hline & & Wingless & Winged \\
\hline 37 & 0 & 52 & 0 \\
\hline 37 & 1 & 40 & 0 \\
\hline 37 & 5 & 38 & 0 \\
\hline 37 & 12 & 37 & 0 \\
\hline 37 & 24 & 63 & 0 \\
\hline 156 & 0 & 56 & 0 \\
\hline 156 & 1 & 35 & 1 \\
\hline 156 & 5 & 71 & 3 \\
\hline 156 & 12 & 75 & 1 \\
\hline 156 & 24 & 13 & 1 \\
\hline 625 & 0 & 49 & 0 \\
\hline 625 & 1 & 59 & 0 \\
\hline 625 & 5 & 55 & 1 \\
\hline 625 & 12 & 52 & 0 \\
\hline 625 & 24 & 46 & 2 \\
\hline 2500 & 0 & 83 & 0 \\
\hline 2500 & 1 & 47 & 0 \\
\hline 2500 & 5 & 54 & 1 \\
\hline 2500 & 12 & 48 & 0 \\
\hline 2500 & 24 & 36 & 1 \\
\hline 10000 & 0 & 60 & 0 \\
\hline 10000 & 1 & 40 & 0 \\
\hline 10000 & 5 & 51 & 1 \\
\hline 10000 & 12 & 73 & 1 \\
\hline 10000 & 24 & 41 & 0 \\
\hline
\end{tabular}

exceedingly small, however, and there appears to be no relation between the intensity of light nor the duration of darkness and the amount of wing-production.

Single exposures to light were effected with greater difficulty. Twenty-six groups of wingless aphids, each on a separate plant, were gradually (over a period of 10 hours) removed from light of about 400 meter-candles intensity to total darkness, and were left in darkness a further period of 12 hours. One of these groups was continued in darkness for 118 hours further to test the effect of the darkness or of the gradual change to darkness. The other 25 groups were brought to light of five different intensities for five different periods, and then returned to darkness for periods of 57 to 79 hours. The plants were then brought to 
Light, Darkness, Temperature and the Wings of Aphids.

Table 9. Showing the effect of a single exposure to light on the offspring of the treated aphids. See text for details of method.

\begin{tabular}{|c|c|c|c|c|}
\hline \multirow{2}{*}{$\begin{array}{l}\text { Intensity of } \\
\text { Light in Meter- } \\
\text { Candles }\end{array}$} & \multirow{2}{*}{$\begin{array}{l}\text { Duration } \\
\text { of Light in } \\
\text { Hours }\end{array}$} & \multicolumn{3}{|c|}{ Offspring } \\
\hline & & Wingless & Winged & $\begin{array}{c}\text { Percentage } \\
\text { winged }\end{array}$ \\
\hline 0 & 0 & 24 & 3 & 11.1 \\
\hline 37 & 1 & 48 & 8 & 14.3 \\
\hline 37 & 2 & 26 & 10 & 27.8 \\
\hline 37 & 5 & 31 & 5 & 13.9 \\
\hline 37 & 12 & 28 & 10 & 26.3 \\
\hline 37 & 23 & 39 & 12 & 23.5 \\
\hline 156 & 1 & 38 & 5 & 11.6 \\
\hline 156 & 2 & 45 & 4 & 8.2 \\
\hline 156 & 5 & 39 & 12 & 23.5 \\
\hline 156 & 12 & 13 & 3 & 18.8 \\
\hline 156 & 23 & 33 & 3 & 8.3 \\
\hline 625 & 1 & 33 & 6 & 15.4 \\
\hline 625 & 2 & 27 & 1 & 3.6 \\
\hline 625 & 5 & 23 & 13 & 36.1 \\
\hline 625 & 12 & 25 & 18 & 41.9 \\
\hline 625 & 23 & 30 & 6 & 16.7 \\
\hline 2500 & 1 & 50 & 10 & 16.7 \\
\hline 2500 & 2 & 15 & 7 & 31.8 \\
\hline 2500 & 5 & 20 & 11 & 35.5 \\
\hline 2500 & 12 & 32 & 13 & 28.9 \\
\hline 2500 & 23 & 35 & 9 & 20.5 \\
\hline 10000 & 1 & 33 & 21 & 39.6 \\
\hline 10000 & 2 & 14 & 12 & 46.2 \\
\hline 10000 & 5 & 32 & 6 & 15.8 \\
\hline 10000 & 12 & 41 & 7 & 14.6 \\
\hline 10000 & 23 & 33 & 20 & 37.7 \\
\hline
\end{tabular}

the light and the aphids allowed to produce offspring for a further 26 hours. The offspring are shown in Table 9.

The small number of offspring procurable in continuous darkness (first line of table 9) furnish an uncertain base from which to estimate the results. The average of all the other groups is above the $11,1 \%$ of winged offspring obtained in darkness alone, and perhaps this excess is to be attributed to the single exposure to light; but the percentages are very irregular and do not bear any apparent relation to either intensity or duration of the exposure.

Single exposures to light of very short duration were tested in a more 
rigid manner in the following experiment. A stock of aphids being kept in continuous light of about 300 meter-candles was removed to 30 metercandles, then gradually over a period of two days to 3 meter-candles, then to total darkness for 35 hours. A few of these were then removed, in light of about 0,1 meter-candle, to a new plant, and at intervals subsequently to two other new plants, the handling being done each time in the same faint light $(0,1$ meter-candle $)$. The offspring of these aphids are recorded in the first line of table 10, where the parents are referred to as not having been exposed to light at all. Other groups of the aphids, after their 35-hour period in total darkness, were removed to new plants, and exposed to light of about 10000 meter-candles for periods ranging from 6 to 50 minutes, after which they were returned to darkness. Twice thereafter, at the end of 39 and 70 hours respectively, they were removed, in light of 0,1 meter-candle, to new plants. Their offspring are recorded in the remaining six lines of table 10 .

Table 10. Showing the effect of single exposures of wingless aphids to strong light, upon wing-production in their offspring.

\begin{tabular}{|c|c|c|c|c|c|c|}
\hline \multirow{3}{*}{$\begin{array}{c}\text { Time of } \\
\text { Exposure of Parents, } \\
\text { in Minutes }\end{array}$} & \multicolumn{6}{|c|}{ Offspring, in Hours After Exposure of Parents to Light } \\
\hline & \multicolumn{2}{|c|}{$0-39$} & \multicolumn{2}{|c|}{$39-70$} & \multicolumn{2}{|c|}{$70-162$} \\
\hline & Wingless & Winged & Wingless & Winged & Wingless & Winged \\
\hline 0 & 27 & 0 & 30 & $\mathbf{5}$ & 70 & 5 \\
\hline 6 & 33 & 6 & 26 & 2 & 56 & 4 \\
\hline 10 & 3 & 3 & 14 & 1 & 9 & 0 \\
\hline 20 & 25 & 4 & 15 & 1 & 45 & 0 \\
\hline 30 & 15 & 3 & 15 & 2 & 36 & 2 \\
\hline 40 & 6 & 4 & 16 & 4 & 70 & 15 \\
\hline 50 & 8 & 4 & 16 & 1 & 15 & 0 \\
\hline
\end{tabular}

While the percentage of winged offspring is somewhat greater on the average in the groups exposed to light than in the one kept continuously in darkness, the difference is not great and the separate percentages are so irregular as to appear meaningless.

Obviously any definite relation of time of exposure and intensity of the light to the amount of wing-production will have to be discovered, if at all, from the results of repeated exposures. This can be more effectively done when the general physiological scheme of wing-production is better understood than at present.

\section{Effect of Length of Initial Exposure to Darkness.}

Although a single exposure to darkness, as just stated, has an insignificant effect on wing-production, an initial period of darkness appears to have an observable effect if it is followed by other repeated 
periods of light and darkness. The extent of this effect depends upon the length of the initial period. This conclusion was reached by sub. jecting six groups of aphids to an initial period of darkness of various durations, ranging from 4 hours to 14 hours, and after that alternating all groups repeatedly between 2 hours of light and 4 hours of darkness. Six other groups of aphids were subjected to initial periods of darkness ranging from 6 to 16 hours, and each was thereafter alternated between 3 hours of light and 6 hours of darkness. These short alternating periods, 2 and 4 hours, and 3 and 6 hours, respectively, had been tested without. any initial period of darkness of greater length, and had been found to have a relatively small, though variable, effect on wing-production (see Table 4 and Fig. 4). It seemed possible that the reason for the smallness of their effect might be that wing-production depends upon building

Table 11. Showing the effect of the length of the initial period of darkness, followed by short periods of uniform duration, upon wing-production in the offspring of aphids.

\begin{tabular}{c|c|c|c|c|c}
\hline $\begin{array}{c}\text { Initial } \\
\text { Period of } \\
\text { Darkness, } \\
\text { in Hours }\end{array}$ & \multicolumn{2}{|c|}{ Subsequent Periods, in Hours } & \multicolumn{3}{c}{ Offspring } \\
\hline 4 & Light & Darkness & Wingless & Winged & $\begin{array}{c}\text { Percentage } \\
\text { winged }\end{array}$ \\
\hline 6 & 2 & 4 & 59 & 21 & 26.3 \\
8 & 2 & 4 & 62 & 24 & 27.9 \\
10 & 2 & 4 & 65 & 20 & 23.5 \\
12 & 2 & 4 & 86 & 35 & 28.9 \\
14 & 2 & 4 & 48 & 69 & 59.4 \\
6 & 2 & 4 & 41 & 62 & 60.2 \\
8 & 3 & 6 & 72 & 27 & 27.3 \\
10 & 3 & 6 & 56 & 23 & 29.1 \\
12 & 3 & 6 & 47 & 23 & 32.9 \\
14 & 3 & 6 & 59 & 63 & 51.6 \\
16 & 3 & 6 & 47 & 60 & 56.1 \\
\hline \multicolumn{2}{l|}{ Continuous light } & & 43 & 62 & 59.0 \\
\hline
\end{tabular}

up a cumulative response, and that, with such short periods, the required level could not, or could barely, be reached within the lifetime of one individual. If this were true, an initial period of darkness of greater length might conceivably help to reach the required level, which then might be maintained even by the shorter alternating periods. This was the idea at the basis of the experiments just described. Their results are given in Table 11 and Figs. 7 and 8.

The percentages of wing-production shown in the first and seventh lines of Table 11 are relatively high, as compared with other experiments

W. Ronx' Archiv f. Entwicklungsmechanik Bd. 115. 
testing these same short alternating periods. The data in these two lines are included in the proper items of Table 4 and Fig. 4, and are part of the reason for what is believed to be an undue height of the left end of the curve in Fig. 4. (See the discussion of that figure.) These rather high percentages, obtained after initial periods of darkness which

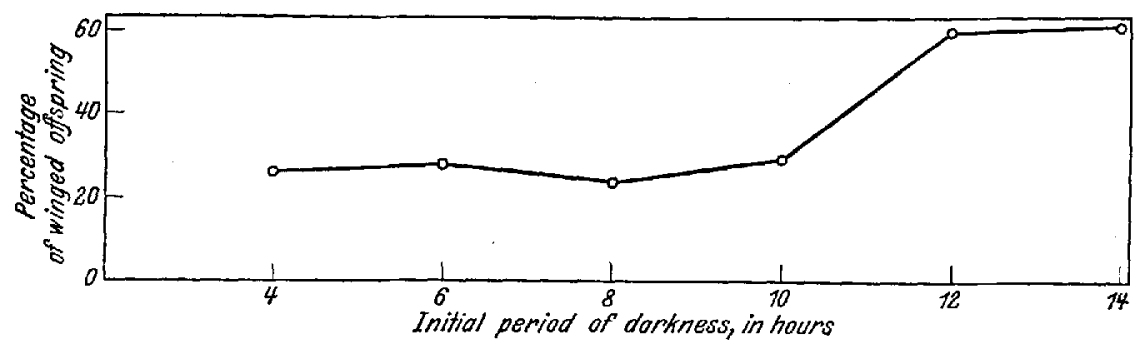

Fig. 7. Curve ghowing the effect, upon wing-production, of an initial period of darkness, of six different lengths, followed by repeated alternations of 2 hours of light and 4 hours of darkness. These repeated short periods were shown, in Fig. 4, to have only a small effect. Here, they are shown to have a larger effect if preceded by a single initial period of darkness more than 10 hours long. The initial period alone has been shown incapable of producing this result.

were of the same length as the subsequent repeated periods of darkness, form the base from which the percentages obtained when the initial periods of darkness were longer must be judged. These percentages of winged offspring are not appreciably altered until the initial period of darkness exceeds 10 hours. For these longer initial dark periods, the curves of wing-production rise very distinctly (see Figs. 7 and 8).

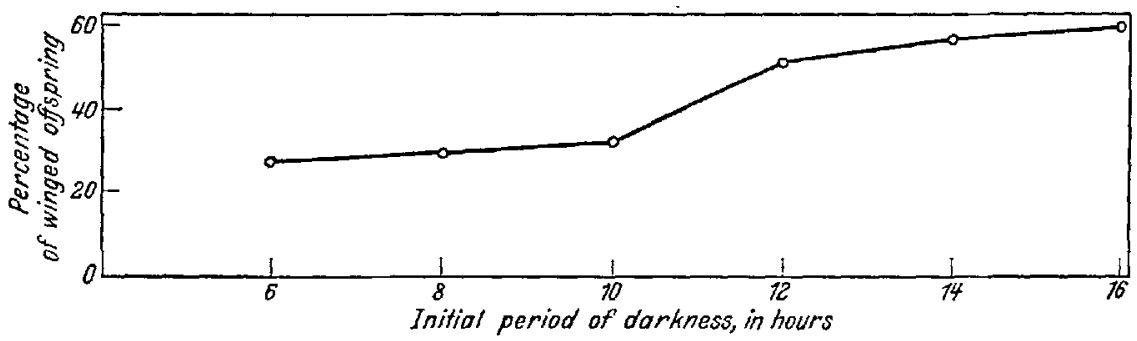

Fig. 8. Curve showing the effect, upon wing-production, of an initial period of darkness, of six different lengths, followed by repeated alternations of 3 hours of light and 6 hours of darkness. These repeated short periods, like those in Fig. 7, were shown in Fig. 4 to have only a small effect. Here they have a more pronounced result if preceded by a dark period more than 10 hours long, which by itself, it has been demonstrated, could not have produced so great an effect.

Whether the effect of the initial periods lasted throughout the lifetime of the parents, or whether it disappeared later in their lives, can not be stated from the data. The parents were transferred from plant to plant at 3-day intervals so that the offspring were abtained in three lots. Unfortunately a wave of male-production occurred at the time of these experiments, and almost all of the offspring in the third lot were males. 
The data on winged parthenogenetic offspring are therefore mostly those of the output of the first six days. The experiments do not, therefore, settle the question whether alternating short periods of light and darkness can maintain wing-production indefinitely or for a long time, once the requisite conditions for it have been attained. They do show, however, that these short alternating periods together with a single initial dark period of greater length, can induce, at least temporarily, an amount of wing-production which neither the initial period alone nor the short repeated periods alone would induce.

\section{Inhibition of Light Effects by Temperature.}

Since, without special precaution, experiments with light were performed at various temperatures, it was important to know what effect, if any, temperature produces. On at least one occasion, mentioned in my former paper (SHuLL 1928), an experiment in summer differed somewhat in its result from the same experiment in winter, leading to the suspicion that temperature had been the cause of the difference.

Table12. Showing the effect of temperature upon the response of wingless aphids to light and darkness, with respect to wing-production in their offspring.

\begin{tabular}{c|c|c|r|r|r}
\hline \multicolumn{2}{c}{ Hours of Exposure } & $\begin{array}{c}\text { Tempera- } \\
\text { ture in.De- } \\
\text { grees Centi- } \\
\text { grade }\end{array}$ & Wingless & winged & $\begin{array}{c}\text { Percentage } \\
\text { winged }\end{array}$ \\
\hline Light & Darkness & 14 & 0 & 431 & 100.0 \\
8 & 16 & 16 & 6 & 521 & 98.8 \\
8 & 16 & 18 & 0 & 421 & 100.0 \\
8 & 16 & 20 & 0 & 180 & 100.0 \\
8 & 16 & 22 & 52 & 321 & 86.1 \\
8 & 16 & 24 & 229 & 223 & 49.3 \\
8 & 16 & 26 & 234 & 0 & 0.0 \\
8 & 16 & 28 & 79 & 0 & 0.0 \\
8 & 16 & 16 & 562 & 26 & 4.4 \\
\hline 24 & 0 & 24 & 1004 & 4 & 0.4 \\
24 & 0 & & & & \\
\hline
\end{tabular}

To test the effect of temperature, wingless aphids were reared in alternating light ( 8 hours) and darkness (16 hours) at eight different temperatures, and in continuous light at two widely separated temperatures. The results are given in table 12. The temperatures were obtained by a brine-refrigeration machine, electrically controlled. They varied as much as one degree on either side of the mean. By means of thermograph records kept for a fair sample of the time at each temperature, and by calculation from half-hourly temperatures as shown by these records, the temperatures called $14^{\circ}, 16^{\circ}$, and $18^{\circ} \mathrm{C}$. in the table were really 
$14,07 \pm 0,26,15,9 \pm 0,19$, and $18,11 \pm 0,22$ respectively. The other temperatures showed similar deviations. Fig. 9 represents the data of Table 12 graphically.

The data show that, in 8 hours of light and 16 hours of darkness, practically all offspring were winged at temperatures from $14^{\circ}$ to $20^{\circ} \mathrm{C}$. Above $20^{\circ}$ the percentage of winged offspring rapidly fell, and at $26^{\circ}$ and above no winged individuals were were produced. In continuous light, regardless of the temperature, nearly all offspring were wingless, though there is a suggestion that low temperature favored wing-production to a small degree (last two lines of table 12).

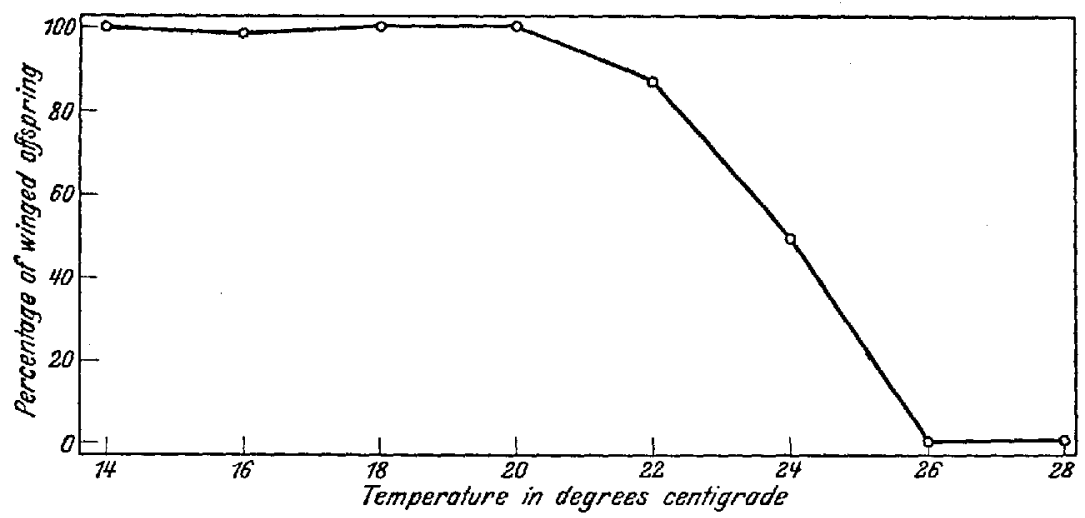

Fig. 9. Curve showing the inhibiting effect of high temperature on wing-production by alternating light and darkness. Alternation of 8 hours light with 16 hours of darkness produces wings in almost all the offspring at all feasible temperatures up to $20^{\circ} \mathrm{C}$., but rapidly loses this effect at higher temperatures.

\section{Alternating Temperatures in Relation to Light.}

The use of alternate high and low temperatures should give information on one or two points: (1) whether continuous high temperature is necessary to inhibit the effect of alternate light and darkness, and, in case the effect of temperature is immediate, (2) whether temperature affects only the processes going on in the light, or only those occurring in darkness, or both.

In one group of aphids, while the parents were in the light continuously, they were at $25^{\circ} \mathrm{C}$. for 8 hours, and at $16^{\circ}$ for 16 hours daily. In a second group the aphids were likewise in continuous light, but at $25^{\circ}$ for 16 hours, and at $16^{\circ}$ for only 8 hours. A third group was kept 8 hours daily in light at $25^{\circ}, 16$ hours in darkness at $16^{\circ}$. A fourth group was in the light 8 hours at $16^{\circ}$, in darkness 16 hours at $25^{\circ}$. The results are given in table 13.

The results of alternating temperatures are about the same as were obtained in the preceding experiments at continuous low temperature. 
Table 13. Showing the influence of alternating temperatures upon the production of wings in aphids by means of alternating light and darkness.

\begin{tabular}{|c|c|c|c|c|c|c|}
\hline \multirow{2}{*}{$\begin{array}{l}\text { Total Hours } \\
\text { of } \\
\text { Light Daily }\end{array}$} & \multicolumn{2}{|c|}{ Hours at $25^{0} \mathrm{C}$. } & \multicolumn{2}{|c|}{ Hours at $16^{3} \mathrm{C}$. } & \multicolumn{2}{|c|}{ Offspring } \\
\hline & In light & In darkness & In light & In darkness & Wingless & Winged \\
\hline 24 & 8 & & 16 & & 582 & 23 \\
\hline 24 & 16 & & 8 & & 65 & 10 \\
\hline 8 & 8 & & & 16 & 6 & 614 \\
\hline 8 & & 16 & 8 & & 0 & 79 \\
\hline
\end{tabular}

A few winged offspring were produced in continuous light (first two lines of table 13) with alternating temperatures just as in continuous low temperature (ninth line of table 12). The proportion of winged offspring was slightly greater when the high temperature was applied 16 hours than when it was used only 8 hours (second line as compared with first line in table 13). Since this is just the reverse of what would be expected from continuous high temperature, the difference is probably due to some other factor. In alternating light and darkness, the offspring were nearly all winged, regardless of whether the high temperature was applied in darkness or light (last two lines of the table).

One would conclude from these facts (1) that high temperature, to inhibit the effect of alternation of light and darkness, must be continuous, or at least nearly so, and (2) that when high and low temperatures are alternated, it is immaterial whether the high temperature is applied in the light or in darkness, the effect, so far as wing-production is concerned, being that of continuous low temperature in either case. The reason for the ineffectiveness of alternating temperatures may merely be that the effect of temperature is not immediate, but considerably delayed, and that with alternating temperatures this effect is largely lost. Some alternative possibilities are discussed in a later section.

\section{Control of Sex Throngh Control of Wings.}

From a knowledge of certain facts regarding the life cycle of this aphid, with which this paper does not directly deal, it is obvious that a measure of sex control has been attained when the means of regulating wing-production have been discovered. Under usual conditions, almost all males are produced by wingless mothers, and nearly all gamic females by winged mothers. What brings on the gamic phase of the cycle is only imperfectly known, but when it does set in the two sexes are definitely related to the winged or wingless condition of the parthenogenetic females that produce them. That relation can be disturbed artificially in some cases, but under ordinary conditions the rule holds, as stated above, that males are produced by wingless, gamic females by winged mothers. 
Any influence, therefore, which governs the production of wings in one generation governs sex in the next generation if gamic individuals are produced in the latter generation. To be specific, if a wingless female is alternated between strong light of 2 to 8 hours duration and darkness of 12 to 14 hours duration, at temperatures not above $20^{\circ} \mathrm{C}$., it is fairly certain that her grandchildren will be females if the conditions are right then for the production of gamic individuals. If, on the contrary, the same wingless aphid were reared in continuous light, whether at low or high temperature, her grandehildren would with equal certainty be males if the conditions were then such as to produce gamic individuals. In the absence of conditions that produce gamic individuals, the grandchildren would of course be parthenogenetic females. Whether these parthenogenetic females would have wings or not would depend, not upon the treatment their grandmothers received, but upon the conditions under which their mothers lived.

\section{Physiological Explanation of Effect of Light and Darkness.}

It seems likely on a priori grounds that wing-development can be explained only by assuming that a substance is present which causes the tissues to fold at the proper time in the wing-bud region. This substance can not be a simple and direct product of the action of light, since in continuous light almost no wings are produced. Nor can it be regarded as a characteristic product of darkness which light might inhibit, because in continuous darkness only a few individuals develop wings. Some mechanism which depends upon alternation of light and darkness is necessary. The following is offered as a plausible scheme.

It is supposed that a substance (A) is produced in the light, that this substance is converted into another substance (B) in darkness, that B is reconverted into $A$ in the light or is consumed in some other reaction or is otherwise eliminated, and that production of wings occurs either when a given concentration of $B$ is present, or when the quantity of $B$ bears a certain ratio to that of $A$. Presumably intense light produces A more rapidly than does weak light, and light of a given intensity produces more A during a long exposure than during a short one. It is assumed that the greater the quantity of $A$ present, the more of $B$ is produced later in darkness. Exceedingly weak light may cause some conversion of $A$ into $B$. For the conversion of $A$ into $B$ periods of darkness of 12 to 14 hours duration are of special significance. Either the process occurs with great rapidity after 10 hours of darkness have elapsed, or this length of iime is necessary to reach a critical level.

High temperature obviously interferes with some part of the above general process. Where this interference occurs is uncertain. The failure of alternate high and low temperatures to prevent wing-production is 
difficult to explain. If the production of $\mathrm{A}$ in the light is a photochemical process, and is therefore assumed to be independent of temperature, and if conversion of $A$ into $B$, not being photochemical, is assumed to be accelerated by high temperature, rearing the aphids at low temperature in the light and at high temperature in darkness would result in the production of more $B$ than is produced when the temperature is low in both light and darkness, or at least as much $B$ if the limit of the amount of $B$ produced is set by the amount of $A$ present at the end of the preceding light period. In either case, assuming that the explanantion offered is correct, there should be at least as many winged offspring in the alternating high and low temperatures (high in darkness, low in light) as in constant low temperature, and since at constant low temperature nearly all are winged, an even greater quantity of $B$ could not be much more effective in producing wings. The experiments with alternating temperatures do show this same high percontage of winged offspring, and the theory so far fits the facts. Likewise, rearing the aphids at high temperature in the light (which would not presumably increase the amount of A produced photochemically), and at low temperature in darkness (which should produce as much $B$ as if the temperature were low in both light and darkness), should result in neither more nor less of $\mathbf{B}$, and honce should result in the same percentage of wing-production. In the experiments this actually happens, and the theory again fits the facts. However, if these assumptions are correct, continuous high temperature (accelerating production of $\mathrm{B}$ in darkness, but not accelerating production of $A$ in the light) should result in at least as much $B$ as would any of the conditions above described, and hence as many winged offspring should be produced. As has been shown, however, few or none of the offspring are winged at continuous high temperatures.

If to avoid this difficulty it be assumed that high temperature retards the conversion of $\mathrm{A}$ into $\mathrm{B}$ while not affecting the photochemical production of $A$, rearing the aphids at low temperature in the light and at high temperature in darkness should diminish the amount of $B$ and hence winged offspring, which it does not do.

An appeal to a differential effect of high temperature upon the rate of development of the embryo and the rate of production of the wingdetermining substance can hardly be made. If the temperature change occurred at the same point in the development of every individual, it might be assumed that high temperature accelerated the development more than it accelerated the production of the substance $B$, and that the embryos arrived at the moment when wings are determined before the amount of $\mathbf{B}$ had reached the critical level. However, the change of temperature occurs at all stage of development, for the different offspring, from oöcyte to birth. For some of them, it would seem, the time available 
to produce B should be great enough to reach the critical level of that substance before wings are determined. Under only one assumption does it seem possible to use the differential rates referred to above as an explanation of the inhibition of wings by high temperature, namely, that the production of $B$ takes place in the embryo instead of the mother, and that it can not begin until the embryo reaches a certain stage of development. So far no method has been devised of ascertaining whether light or temperature acts directly on the embryo or indirectly through changes in the mother.

It may be possible to avoid all these difficulties by assuming that temperature requires a longer time to affect the chemical processes involved, and that alternations of temperature every day result in a confused effect that does not differentiate between the production of $A$ and that of $B$. At the present stage of these investigations the last-named possibility appears the most likely. It is probably open to further experimental test.

\section{Summary.}

When the parent aphids were alternated once a day between light of low intensity and total darkness, for periods ranging (for the light) from 5 minutes to 24 hours, the number of offspring having wings increased with increase in the duration of light up to 8 hours of light, decreased slightly thereafter up to 12 hours of light, dropped suddenly as the duration of the light increased from 12 to 14 hours, and remained low for all longer periods of light.

When more intense light was used, with the same periods of alternation, the curve of wing-production was higher for all durations of light up to 12 hours, but was nearly identical with the curve for low intensity for all daily durations of light greater than 12 hours.

Alternating the aphids between strong and weak light had little effect on wing-production in their offspring unless the weak light were of 1.6 meter-candles intensity, or less. Alternating with weak light of 1.6 meter-candles, the stronger light was necessarily of 323 meter-candles intensity, or more, to produce many wings.

Alternating the aphids between light and darkness of various periods in the ratio of $1: 2$ had relatively small effect on wing-production if the periods were less than 5 hours of light and 10 hours of darkness. The maximum effect was obtained with 6,25 hours of light and 12,5 hours of darkness: With longer periods, the effect gradually decreased.

Light and darkness in the time ratios of $1: 3$ and $1: 4$ were about as effective as in the ratio of $1: 2$. In the ratio of $1: 1$, the alternation was somewhat less effective. In all cases, to be very effective, the period of darkness was necessarily 12 hours or more in length.

Twelve hours of darkness alternated with various periods of light 
produced many wings if the light periods were 2 to 6 hours long, with the maximum effect probably obtained with 6 hours. Longer periods of light produced gradually fewer wings, until at 20 hours of light and 12 hours of darkness the effect was almost completely lacking.

Alternating 6 hours of light with various periods of darknesis gave little wing-production with periods of darkness less than 10 hours. There was a sharp increase as the darkness increased from 10 to 12 hours, a maximum effect with darkness of 12 to 14 hours, and a gradual decline for longer periods.

Single exposures to light or to darkness produced relatively small and highly irregular effects on wing-production. To obtain the results described above the exposures must be repeated. Nevertheless, an initial period of darkness of 12 hours or more, which by itself was shown to have little effect, followed by alternation of short periods of light and darkness ( 2 and 4 hours, and 3 and 6 hours) which also had relatively small effect by itself, caused a distinct increase of wing-production. In this sense a single period of darkness was effective.

Alternation of light and darkness of 8 hours and 16 hours, respectively, caused wing-production at all feasible temperatures not over $20^{\circ} \mathrm{C}$. At temperatures above $20^{\circ} \mathrm{C}$. wing-production declined, and at $26^{\circ}$ and above totally ceased. Presumably all other alternating periods that were found effective would fail to produce wings at these high temperatures. The temperature need not be below $20^{\circ}$ all of the time. If temperatures were alternately high and low, they might be high either in the light or in the dark periods, without preventing wing-production.

Sex-determination is in a sense controllable through wing-production. Since under usual conditions almost all males are produced by wingless mothers, and almost all gamic females by winged mothers, control of wings in one generation means virtual control of sex in the following generation in so far as gamic individuals are produced in the latter generation.

To explain the control of wing-production by light and darkness, it is assumed that some substance is produced in the light, that this is converted into another substance in darkness, that the second substance is reconverted into the first when light returns or is otherwise consumed, and that wings are produced either when the second substance is present in a certain concentration or when it bears a certain quantitative relation to the first substance. High temperature inhibits some part of the process.

\section{Zusammenfassung.}

Wenn man die Eltern-Aphiden dieser Spezies täglich abwechselnd schwachem Licht und völliger Dunkelheit aussetzt, bei Hellperioden von 5 Minuten bis 24 Stunden, so steigt die Zahl der geflügelten Nach-

W. Roux' Archiv f. Entwicklungsmechanik Bd. 115. 
kommen je nach der Dauer der Lichtperioden bis zu einem Maximum bei 8 Stunden Licht, danach sinkt die Zahl langsam bis zur 12stündigen Belichtung, dann schnell von 12-14 Stunden Licht, und bleibt niedrig bei allen längeren täglichen Hellperioden.

Bei stärkerem Licht und denselben Wechselperioden von Licht und Dunkelheit wie oben ist die Zahl der Geflügelten größer bei allen Lichtperioden bis zu 12 Stunden, aber bei allen längeren täglichen Hellperioden bleibt sie derjenigen für schwache Beleuchtung fast gleich.

Wechseln die Aphiden zwischen hellem und schwachem Licht ab, so ist der Prozentsatz der geflügelten Nachkommen nur dann bedeutend, wenn die Intensität des schwächeren Lichtes nicht mehr als 1,6 Meterkerzen ist. Hat das schwächere Licht eine Intensität von 1,6 Meterkerzen, so muß das stärkere Licht eine Intensität von mindestens 323 Meterkerzen haben, um einen beträchtlichen Prozentsatz von geflügelten Nachkommen hervorzubringen.

Wenn die Wechselperioden von Licht und Dunkelheit im Verhältnis von $1 \mathrm{zu} 2$ stehen, so ist die Menge der Geflügelten ziemlich gering, solange die Perioden nicht länger als 5 Stunden Licht und 10 Stunden Dunkelheit danern. Der größte Prozentsatz von geflügelten Nachkommen geht aus 6,25 Stunden. Licht und 12,5 Stunden Dunkelheit hervor. Bei längeren Perioden in demselben Verhältnis nimmt die Zahl allmäh. lich $a b$.

Licht und Dunkelheit im Verhältnis von 1 zu 3 oder 1 zu 4 sind ungefähr ebenso wirkungsvoll wie im Verhältnis von 1 zu 2, aber im Ver. hältnis von $1 \mathrm{zu} l$ wirken sie in geringerem Grade. Um großen Erfolg zu haben, muß die Dunkelheit jedenfalls mindestens 12 Stunden dauern.

Unterwirft man die Aphiden abwechselnd 12 Stunden Dunkelheit und verschiedenen Lichtperioden, so sind die geflügelten Nachkommen am zahlreichsten bei Hellperioden von 2-6 Stunden. Die 6-Stundenlichtperioden sind wahrscheinlich am wirkungsvollsten. Bei längeren Hellperioden vermindert sich die Zahl der Geflügelten bis zu 20 Stunden Licht auf 12 Stunden Dunkelheit, wo sie nur spärlich mehr vorkommen.

Werden die Aphiden abwechselnd 6 Stunden Licht und verschiedenen Dunkelperioden unterworfen, so ist der Prozentsatz der geflügelten Nach. kommen bei Dunkelperioden von weniger als 10 Stunden relativ klein, steigt aber sehr schnell bei Verlängerung der Dunkelperioden von 10 bis 12 Stunden, bleibt hoch bis 14 Stunden Dunkelheit und fällt bei längeren Dunkelperioden allmählich ab.

Setzt man die Eltern nur einmal dem Lichte oder der Dunkelheit aus, so hat das eine relativ geringe und unregelmäßige Wirkung auf Flügelentwicklung. Man muß mehrmals abwechseln, um die eben angegebenen Resultate zu erhalten. Doch hat eine einzige 12 Stunden oder länger dauernde Dunkelperiode, welche allein keine beträchtliche Wirkung hat, 
eine deutliche Wirkung, wenn eine Reihe von abwechselnden kurzen Hellund Dunkelperioden (2 und 4 Stunden oder 3 und 6 Stunden) darauf folgt, die allein auch eine relativ geringe Wirkung haben. In diesem Sinne hat eine einzige Dunkelperiode einen Effekt.

Der Wechsel von 8stündigem Licht und 16stündiger Dunkelheit verursacht Flügelentwicklung bei allen brauchbaren Temperaturen bis zu $20^{\circ} \mathrm{C}$. Bei höheren Temperatụren fällt die Zahl der geflügelten Nachkommen schnell ab, so daß sie bei $26^{\circ} \mathrm{C}$. (und mehr) Nüll wird. Vermutlich würden alle sonstigen gewöhnlich wirksamen Wechselperioden von Licht und Dunkelheit bei diesen hohen Temperaturen keine Flügel hervorrufen. Die Temperatur braucht nicht ununterbrochen unter $20^{\circ} \mathrm{C}$. zu bleiben, um Flügelentwicklung zu ermöglichen. Wenn die Temperatur abwechselnd hoch und niedrig ist, so kann sie entweder im Licht oder in der Dunkelheit hoch sein, ohne daß sie die Flügelbildung verhindert.

Geschlechtsbestimmung ist durch Flügelentwicklung gewissermaßen kontrollierbar. Da die Männchen unter gewöhnlichen Umständen fast immer von flügellosen Weibchen, und die geschlechtlichen Weibchen fast immer von geflügelten Weibchen erzeugt werden, so ist Bestimmung der Flügel in einer Generation fast identisch mit Bestimmung des Geschlechts in der folgenden Generation, insofern geschlechtliche Aphiden in dieser Generation vorkommen.

Zur Erklärung der Abhängigkeit der Flügelerzeugung von Licht und Dunkelheit könnte man annehmen, daß eine Substanz unter Beleuchtung gebildet wird, daß diese Substanz sich in der Dunkelheit in eine andere verwandelt, daß diese zweite Substanz unter darauffolgender Beleuchtung wieder in die erste umgebildet, oder auf andere Weise zerstört oder entfernt wird, und daß die Aphiden Flügel entwickeln, wenn die zweite Substanz in einer gewissen Konzentration oder in einem bestimmten Verhältnis zur ersten Substanz vorhanden ist. Hohe Temperatur hemmt vielleicht irgendeinen Teil dieses Prozesses.

\section{Bibliography.}

The paper here cited contains, a list of other recent papers dealing with light and the production of wings by aphids, and the first paper of that list contains a bibliography of the older literature dealing with other wing-producing agents.

Shull, A. F. (1928): Duration of light and the wings of the aphid Macrosiphum solanifolii. Roux' Arch. 113, H. 1, 210-239. 